\title{
DUKUNGAN KELUARGA TERHADAP KUALITAS HIDUP KLIEN KANKER STADIUM III DAN IV DI RUMAH SAKIT KANKER
}

\author{
Layya Notiva Dewi ${ }^{1}$, Ice Yulia Wardani ${ }^{1}$ \\ ${ }^{1}$ Keilmuan Keperawatan Jiwa, Fakultas Ilmu Keperawatan Universitas Indonesia \\ layya.notiva@gmail.com
}

\begin{abstract}
Abstrak
Angka kejadian kanker stadium III dan IV pada usia dewasa semakin meningkat tiap tahunnya. Penelitian ini bertujuan untuk mengetahui hubungan dukungan keluarga dengan kualitas hidup anggota keluarganya yang menderita kanker stadium III dan IV. Desain penelitian yang digunakan deskriptif korelatif dengan metode analisis univariat dan bivariat. Jumlah sampel 79 responden. Hasil penelitian didapatkan tidak ada hubungan signifikan antara dukungan keluarga yang meliputi dukungan emosional, dukungan instrumental, dukungan informasi, dan dukungan penghargaan terhadap kualitas hidup klien kanker stadium III dan IV. Perawat dalam menghadapi klien sebaiknya menggali koping adaptif, aspek positif, dan aspek spiritualitas klien tidak hanya memberikan dukungan psikologis dalam upaya peningkatan kualitas hidup klien itu sendiri.

Kata kunci: dukungan keluarga; kualitas hidup; kanker.
\end{abstract}

\begin{abstract}
The incidence of stage III and stage IV cancer in adulthood is increasing every year. This study aims to determine the relationship of the family support to quality of life of family members who have stage III and/or stage IV cancer. The design study is descriptive correlative with univariate and bivariate analysis methods. The numbers of respondents are 79. The results showed no significant relationship between family supports includes emotional support, instrumental support, informational support, appraisal support and the quality of life of clients who have stage III and IV cancer. In dealing with clients, nurses should explore adaptive coping, positive, and spiritual aspects of the client, not only provide psychological support to improving quality of life of the client itself.

Keywords: family support; quality of life; cancer
\end{abstract}

\section{Pendahuluan}

Hidup sehat terbebas dari penyakit baik menular ataupun tidak menular merupakan hal yang diinginkan bagi setiap manusia. Menurut laporan Badan Kesehatan Dunia (WHO) tahun 2003 yang dikutip dalam vivanews, setiap tahun timbul lebih dari 10 juta kasus penderita baru kanker dengan prediksi peningkatan setiap tahun kurang lebih $20 \%$. Jika tidak dikendalikan, diperkirakan 26 juta orang akan menderita kanker dan 17 juta meninggal karena kanker pada tahun 2030 (International Union Against Cancer /UICC, 2009 dalam YKI, Jakarta Race). Di Jakarta sendiri, terdapat Rumah Sakit Kanker di Jakarta yang merupakan jenis rumah sakit pusat nasional bagi klien kanker. Prevalensi kanker disana cukup tinggi. Kematian klien laki-laki dan perempuan penderita kanker di rentang tahun 2003-2007 mencapai skor 20,45. Prevalensi untuk stadium III dan IV memiliki proporsi lebih tinggi dari tingkatan lainnya, yaitu pada stadium III menembus skor $15.87 \%$ sedangkan stadium IV itu sendiri sebanyak $13.02 \%$ (Sinuraya, 2012).

Dukungan sosial merupakan prediktor kesehatan dan kematian seseorang. Perubahan dalam dukungan social secara signifikan memberikan perubahan pada kualitas hidup (Bennet, Perkins, Lane, Deer, Brater, dan Murray, 2001). Bowling dan Windsor (2001) dalam Models of quality of life menyatakan berdasarkan survey nasional orang dewasa di Britania tentang enam hal penting dalam hidup, dengan proporsi responden terbesar orang dewasa (53\%) menyatakan hubungan dengan keluarga, teman, dan lainnya (tetangga) merupakan hal yang paling penting. Kane (1998) dalam Friedman (1998) mendefinisikan dukungan sosial keluarga sebagai suatu proses hubungan antara keluarga dengan 
lingkungannya. Montazeri (1996) dalam Brown, Bowling, Flynn (2004) mewawancarai 200 klien dengan kanker paru-paru dan penyakit pernapasan kronik mengatakan bahwa aspek keluarga disebutkan mampu memberikan kualitas hidup yang baik dengan skor sebesar $58 \%$.

Kondisi psikologis dan sosial yang stabil, secara langsung atau tidak langsung dapat meningkatkan kualitas hidup klien menjadi lebih baik (Damayanti, Fitriyah, \& Indriani, 2008). Kualitas hidup itu sendiri oleh WHO (1997) didefinisikan sebagai persepsi individual dari posisi mereka dalam konteks budaya dan sistem nilai dimana mereka hidup yang berkaitan dengan tujuan, harapan, dan kekhawatirannya. Dalam penelitian telah diketahui bahwa penyakit kronik yang diderita salah satu anggota keluarga dalam suatu keluarga dapat mempengaruhi semua aspek kehidupan keluarga (Pihl, Jacobsson, Fridlund, Stromberg, Martensson, 2005). Pemikiran yang optimis dapat meningkatkan harapan hidup dan memperbaiki kualitas hidup penderita kanker (Peters-Golden, dalam Taylor, 1999).

Dari sekian prevalensi kanker yang terdapat di Rumah Sakit Kanker di Jakarta, belum ada data yang memperlihatkan kualitas hidup klien kanker stadium III dan IV. Demikian juga penelitian terkait hubungan dukungan keluarga terhadap kualitas hidup anggota keluarganya yang menderita kanker stadium III dan IV masih jarang diteliti, dimana data ini dapat menjadi tolak ukur bagi tenaga kesehatan dalam menilai kualitas hidup klien, khususnya bagi perawat untuk lebih memahami bagaimana berkomunikasi dengan klien dalam upaya menggali koping yang dimiliki. Penelitian ini bertujuan untuk mengetahui hubungan dukungan keluarga terhadap kualitas hidup klien kanker stadium III dan IV di Rumah Sakit Kanker di Jakarta dengan menggunakan kuesioner dukungan keluarga dan kuesioner EORTC QLQ C30 .

\section{Metode}

Desain penelitian yang digunakan pada penelitian ini adalah desain penelitian deskriptif korelatif. Populasi dalam penelitian ini merupakan seluruh klien kanker yang datang berobat ke Rumah Sakit Kanker di Jakarta (Rumah Sakit Kanker di Jakarta) terhitung sejak 3 Mei hingga 3 Juni 2013. Sedangkan sampel penelitian sebanyak 79 responden sesuai dengan kriteria inklusi; klien kanker stadium III dan IV yang berobat di Rumah Sakit Kanker di Jakarta dan memiliki anggota keluarga, berusia lebih dari sama dengan 18 tahun, memahami bahasa Indonesia, bersedia menjadi responden. Teknik pengambilan sampel yang digunakan yaitu purposive sampling. Analisis data menggunakan analisis univariat dan bivariat. Sedangkan etika dalam penelitian ini adalah beneficence, privacy, Anonimity dan Confidentiality.

\section{Hasil}

Karakteristik responden dapat pada tabel 1. Tabel 1 didapatkan informasi mengenai karakteristik responden di Rumah Sakit Kanker di Jakarta. Responden lebih banyak yang berjenis kelamin perempuan daripada laki-laki sebesar 79,7\%. Sedangkan untuk usia responden, kebanyakan responden berada pada usia dewasa tengah (rata-rata usia 47.05 tahun). Tingkat pendidikan yang paling banyak ditempuh yaitu SMA sebanyak $35.4 \%$ dan yang berpenghasilan lebih dari UMP 32.9\%. Lama responden yang terdiagnosa kanker kurang dari 22 bulan sebesar $50.6 \%$ sedangkan yang lebih dari 22 bulan sebesar 49.4\%. Namun, tingkat keparahan responden yang lebih tinggi justru pada stadium III yaitu $70.9 \%$. Sebagian besar untuk jenis pengobatan yang saat ini sedang atau pun yang paling akhir mereka jalani yaitu kombinasi dengan proporsi $68.4 \%$, diikuti kemoterapi sebesar $19 \%$, radiasi $8.9 \%$ dan yang paling sedikit dijalani yaitu operasi $3.8 \%$. 
Tabel 1. Karakteristik Responden

\begin{tabular}{lcc}
\hline \multicolumn{1}{c}{ Variabel } & $\mathrm{f}$ & $\%$ \\
\hline Jenis Kelamin & 63 & 79.7 \\
Perempuan & 16 & 20.3 \\
Laki-laki & & \\
Usia & 23 & 29.1 \\
Dewasa Awal & 45 & 57.0 \\
Dewasa Tengah & 11 & 13.9 \\
Dewasa Akhir & & \\
Tingkat pendidikan & 2 & 2.5 \\
Tidak sekolah & 17 & 21.5 \\
SD & 10 & 12.7 \\
SLTP & 28 & 35.4 \\
SMA & 22 & 27.8 \\
Perguruan tinggi & & \\
Tingkat ekonomi & 26 & 32.9 \\
Lebih dari UMP & 53 & 67.1 \\
Kurang dari UMP & & \\
Lama terdiagnosa kanker & 40 & 50.6 \\
Kurang dari 22 bulan & 39 & 49,4 \\
Lebih dari 22 bulan & & \\
Tingkat keparahan & & 70,9 \\
Stadium III & 56 & 29,1 \\
Stadium IV & 23 & 19.0 \\
Jenis pengobatan & & 8.9 \\
kemoterapi & 15 & 3.8 \\
Radiasi & 7 & 68.4 \\
Operasi & 3 & \\
Kombinasi & 54 & \\
\hline
\end{tabular}

Tabel 2. Dukungan keluarga dan kualitas hidup

\begin{tabular}{ccc}
\hline Variabel & f & $\%$ \\
\hline Dukungan emosional & & \\
\hline Kurang baik & 32 & 40.5 \\
Baik & 47 & 59.5 \\
\hline
\end{tabular}

Dukungan Instrumental

$\begin{array}{lll}\text { Kurang baik } & 29 & 36.7 \\ \text { Baik } & 50 & 63.3\end{array}$

Dukungan informasi

$\begin{array}{lll}\text { Kurang baik } & 31 & 39.2 \\ \text { Baik } & 48 & 60.8\end{array}$

Dukungan penghargaan

$\begin{array}{lll}\text { Kurang baik } & 37 & 46.8 \\ \text { Baik } & 42 & 53.2\end{array}$

Kualitas hidup

$\begin{array}{llr}\text { Kurang baik } & 39 & 49.4 \\ \text { Baik } & 40 & 50.6\end{array}$

Tabel 2 distibusi frekuensi emosional kategori baik sebesar $59.5 \%$, menunjukkan variabel dukungan keluarga sedangkan untuk kategori kurang baik dan kualitas hidup. Dari tabel diatas 40.5\%. Demikian juga dengan dukungan terlihat bahwa secara keseluruhan, instrumental, untuk kategori baik responden mendapatkan dukungan proporsinya lebih tinggi yaitu sebesar keluarga kategori baik. Dukungan 63.3\% dari kategori kurang baik. 
Sub variabel yang ketiga yaitu sub variabel dukungan informasi. Dari data terlihat dukungan informasi yang diperoleh sebagian besar berada pada kategori baik yaitu $60.8 \%$. Sedangkan pada dukungan penghargaan, sebesar $53.2 \%$ berada pada kategori baik dan sisanya sebesar $46.8 \%$ berada pada kategori kurang baik. Selain informasi mengenai dukungan keluarga, data di atas juga menunjukkan distribusi frekuensi kualitas hidup responden. Dari data terlihat bahwa responden yang memiliki kualitas hidup baik sebanyak 39 responden $(49.4 \%)$ dari 79 responden. Sedangkan kualitas hidup kurang baik proporsinya lebih banyak yaitu $50.6 \%$.

Tabel 3. Hubungan Dukungan Keluarga dengan Kualitas Hidup Responden

\begin{tabular}{|c|c|c|c|c|}
\hline \multirow{3}{*}{ Variabel } & \multicolumn{4}{|c|}{ Kualitas hidup } \\
\hline & \multicolumn{2}{|c|}{ Kurang baik } & \multicolumn{2}{|c|}{ Baik } \\
\hline & $\mathrm{f}$ & $\%$ & $\mathrm{f}$ & $\%$ \\
\hline \multicolumn{5}{|l|}{ Dukungan emosional } \\
\hline Kurang baik & 17 & 53.1 & 15 & 46.9 \\
\hline Baik & 23 & 48.9 & 24 & 51.1 \\
\hline \multicolumn{5}{|l|}{ Dukugan Instrumental } \\
\hline Kurang baik & 15 & 51.7 & 14 & 48.3 \\
\hline Baik & 25 & 50.0 & 25 & 50.0 \\
\hline \multicolumn{5}{|l|}{ Dukungan informasi } \\
\hline Kurang baik & 15 & 48.4 & 16 & 51.6 \\
\hline Baik & 25 & 52.1 & 23 & 47.9 \\
\hline
\end{tabular}

Dukungan penghargaan

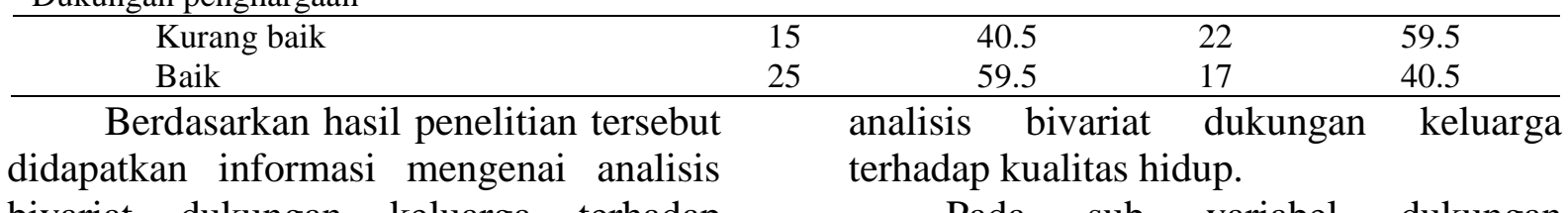
bivariat dukungan keluarga terhadap kualitas hidup. Untuk sub variable dukungan emosional, responden yang mendapatkan dukungan emosional kurang baik dan kualitas hidup kurang baik proporsinya paling tinggi jika dibandingkan kategori lainnya yaitu sebesar $53.1 \%$. Analisis lebih lanjut pada alpha 5\% tidak terdapat hubungan yang bermakna antara dukungan emosional dengan kualitas hidup klien kanker stadium III dan IV ( $\mathrm{p}=0.892 ; \alpha=0.05)$. Yang kedua, yaitu sub variabel dukungan instrumental kurang baik maka kualitas hidup responden kurang baik sebesar $51.7 \%$. Analisis lebih lanjut pada alpha 5\% tidak terdapat hubungan yang bermakna antara dukungan instrumental dengan kualitas hidup kanker stadium III dan IV $(p=1.000 ; \alpha=0.05)$. Dari tabel penelitian di atas didapatkan informasi mengenai

Pada sub variabel dukungan informasi baik maka kualitas hidup kurang baik $52.1 \%$. Analisis lebih lanjut pada alpha 5\% tidak terdapat hubungan yang bermakna antara dukungan instrumental dengan kualitas hidup klien kanker stadium III dan IV $(p=0.928 ; \alpha=0.05)$. Sub variabel yang terakhir yaitu dukungan penghargaan baik memiliki kualitas hidup yang kurang baik dibuktikan dengan proporsi sebesar $59.5 \%$. Analisis lebih lanjut pada alpha 5\% tidak terdapat hubungan yang bermakna antara dukungan penghargaan dengan kualitas hidup klien kanker stadium III dan IV.

\section{Pembahasan}

Penelitian yang dilakukan peneliti memberikan informasi bahwa responden yang terdiagosa kanker stadium III dan IV sebagian besar berada pada rentang usia dewasa tengah yaitu usia 40 hingga 60 
tahun. Hubungan antara usia dan kanker telah diteliti oleh Anisimov, Sikora, dan Pawelec (2009) salah satunya menyatakan bahwa prevalensi kanker yang tinggi pada usia tua merupakan akibat dari lamanya terpajan karsinogen. Untuk hasil penelitian yang dilakukan peneliti mengenai gambaran karakteristik, peneliti mendapatkan dukungan dari penelitian sebelumnya yaitu penelitian Montazeri, Hole, Milroy, McEwen, dan Gillis (2003) yang mendapatkan hasil bahwa tingkat sosial ekonomi yang rendah pada klien kanker paru-paru memiliki lebih banyak masalah kesehatan, fungsi fisik yang kurang, dan gejala yang berlebih dibandingkan responden yang tingkat sosial ekonominya lebih tinggi. Selain itu, penelitian Wijaya (2011) menyatakan bahwa tidak terdapat hubungan antara pengetahuan dengan angka terjadinya kanker.

Hasil uji bivariat penelitian yang dilakukan peneliti menunjukkan tidak ada hubungan yang signifikan antara dukungan emosional terhadap kualitas hidup. Namun, tidak adanya hubungan antara dua variable tersebut bukan berarti tidak memberikan pengaruh bagi kualitas hidup responden. Hasil uji bivariat pada variabel dukungan instrumental dan kualitas hidup didapatkan informasi bahwa tidak ada hubungan yang signifikan antar kedua variable tersebut. Penelitian yang dilakukan oleh Finfgeld dan Connet (2005) dalam Sjolander dan Ahlstrom (2012) memberikan dukungan terhadap penelitian yang dilakukan peneliti dibuktikan dengan responden yang mendapatkan dukungan instrumental buruk, kualitas hidupnya juga buruk. Finfgeld dan Connet (2005) juga menunjukkan bahwa klien kanker stadium lanjut membutuhkan dukungan instrumental sehingga mampu meningkatkan kesehatan mental klien. Kesehatan mental klien secara tidak langsung akan mempengaruhi persepsi klien tentang penyakitnya dan pada akhirnya akan meningkatkan kualitas hidup.
Analisis bivariat yang selanjutnya yaitu dukungan informasi dan kualitas hidup. Hasil uji tersebut menunjukkan tidak ada hubungan yang signifikan antara dukungan informasi dan kualitas hidup. Penelitian yang dilakukan oleh Mitchell \& Glicksman, 1977; Peck \& Bowland, 1977 dalam Helgeson dan Cohen 1996 menunjukkan bahwa klien kanker hanya membutuhkan dukungan informasi terkait penyakit yang diderita oleh seorang tenaga profesional. Hal itu dirasakan penting oleh klien dan keluarga sehingga menunjukkan bahwa petugas pelayanan kesehatan dan pada akhirya akan meningkatkan kualitas hidup klien/penderita (Sjolander dan Ahlstrom, 2012). Hasil tersebut memperkuat penelitian yang peneliti lakukan bahwa jika dukungan informasi dari keluarga baik, belum tentu kualitas hidup yang dirasakan responden juga baik.

Uji bivariat yang terakhir yaitu uji bivariat dukungan penghargaan terhadap kualias hidup. Hasil tersebut menunjukkan tidak ada hubungan signifikan antara dukungan penghargaan terhadap kualitas hidup. Hasil penelitian didukung oleh penelitian yang dilakukan Taylor, Falke, Shoptaw, dan Lichtman (1986) yang memberikan hasil bahwa dukungan penghargaan hanya dibutuhkan oleh responden terkait kualitas hidup dengan proporsi sedikit. Menurut Weis (2003) dalam artikel yang ditulisnya, terdapat bukti yang nyata bahwa klien yang cenderung memiliki perasaan menghindar/ menolak terhadap diagnosa kanker yang diterimanya, merasa khawatir dan mengalami isolasi sosial berhubungan dengan kesehatan yang buruk dan kualitas hidup yang buruk. Penelitian selanjutnya jika akan melakukan penelitian yang terkait kanker stadium III dan IV, sebaiknya lebih dikhususkan untuk kanker jenis tertentu. Hal ini disebabkan untuk setiap jenis kanker memiliki gejala dan efek yang berbeda-beda sehingga kualitas hidup yang dirasakan pun akan berbeda sehingga hasil yang didapatkan dalam penelitian lebih akurat. 


\section{Simpulan dan Saran}

Secara umum, kualitas hidup yang dimiliki klien kanker di Rumah Sakit Kanker di Jakarta periode Mei-Juni 2013 kurang baik. Koping yang dimiliki masing-masing individu dalam menghadapi penyakit yang dideritanya berbeda-beda. Dukungan sosial dan lingkungan sosial bagi klien kanker dapat langsung mempengaruhi strategi koping yang meliputi proses emosional, kognitif dan perilaku. Dengan adanya strategi koping yang adekuat, maka akan semakin positif persepsi klien tentang penyakit yang dideritanya sehingga mampu meningkatkan kualitas hidup.

Penelitian ini dapat menjadi pertimbangan bagi institusi pelayanan kesehatan agar dalam setiap ruangan misalnya rawat jalan dan juga rawat inap terdapat perawat khusus jiwa. Perhatian dan kepedulian dari tenaga kesehatan terhadap klien mampu mempengaruhi kualitas hidup klien.

Penelitian selanjutnya diharapkan mahasiswa keperawatan agar dalam mempelajari sebuah ilmu dalam hal ini ilmu mengenai kejiwaan (psikologis) tidak hanya ditinjau dari teori yang ada. Akan tetapi menyesuaikan sebenarnya dukungan apa saja yang sebenarnya klien butuhkan dari keluarga atau sumber pemberi dukungan lainnya. Dukungan yang tepat diberikan kepada klien kanker akan meningkatkan kualitas hidup menjadi lebih baik.

\section{Daftar Pustaka}

Anggraeni, M.D. dan Ekowati, W. (2010). Peran keluarga dalam memberikan dukungan terhadap pencapaian integritas diri pasien kanker payudara post radikal mastektomi. Jurnal Keperawatan Soedirman, Volume 5, No.2, Juli 2010.

Anisimov, V.N., Sikora, E., Pawelec, G. (2009). Relationships between cancer and aging: a multikevel approach. UK: springer science.
Bennet, S.J., Perkins, S.M., Lane, K.A., Deer, M., Brater, D.C., dan Murray, M.D. (2001). Social support and health-related quality of life in chronic heart failure patients. Journal Quality of Life Research 10:671-682.

Bifulco, et al. (2011). Quality of life, lifestyle behavior, and employment experience: A comparison between young and midlife survivors of gynecology eary stage cancers. Journal Gynecologic Oncology (2012) 444-451.

Brown, J., Bowling, A., Flynn, T. (2004). Models of quality of life: A taxonomy, overview and systematic review of the literature. Europan forum on population ageing research.

Damayanti, A.D., Fitriyah, \& Indriani. (2008). Penanganan masalah sosial dan psikologis pasien kanker stadium lanjut dalam perawatan paliatif. Indonesian Journal of Cancer, 1, 30-34.

Deshields, et al. (2012). Psychosocial aspects of caregiving: perceptions of cancer patients and family caregivers. Journal Support Care Cancer. eldridge (2012). Incidence of Lung Cancer in Women.

Fitriana, N.A., dan Ambarini, T.K. (2012). Kualitas hidup pada penderita kanker seviks yang menjalani pengobatan radioterapi. Jurnal Psikologi Klinis dan Kesehatan Mental.

Friedman, M.M. (1998). Family nursing, theory and practice. Coonecticut: Appleton \& Lange.

Helgeson, V.S., Cohen, S. (1996). Social support and adjustment to cancer: reconciling descriptive, correlational, and intervention 
research. Health psychology. 1996. Vol.15. No.2. 135-148.

Lheureux, et al. (2003). Quality of life in lung cancer: does disclosure of the diagnosis have an impact?. Journal Lung Cancer (2004) 43, 175-182.

Malas bergerak risikonya kanker. http://dunia.news.viva.co.id/news/rea d/32674_malas_bergerak_resikonya_k anker. Oktober, 23. 2012.

Mehnert, A. dan Koch, U. (2007). Psychological comorbidity and health-related quality of life and its association with awareness, utilization, and need for psychosocial support in a cancer register-based sample of long-term breast cancer survivors. Journal of Psychosomatic Research 64 (2008) 383-391.

Montazeri, A., Hole, D.J., Milroy, R., McEwen, J. dan Gillis. (2003). Quality of life in lung cancer patients: does socioeconomic status matter?. Journal Health and Quality of Life Outcomes.

Pehlivan, S., Ovayolu, O., Nimet, O., Sevine, A., dan Camci. (2011). Relationships between hopeless, loneliness, and perceived social support from family in Turkish patients with cancer. Journal Support Care Center.

Pihl, E., Jacobson, A., Fridlund, B., Stromberg, A., dan Martensson, J. (2005). Depression and healthrelated quality of life in elderly patients suffering from heart failure and their spouses: A comparative study. The Europan Journal of Heart Failure 7 (2005) 583-589. Elsevier.

Sari, Q.N.R. (n.d.) Dukungan sosial pada penderita kanker payudara di masa dewasa tengah. Jurnal

Fakultas Psikologi, Universitas

Gunadarma.

Siburian, C.H. dan Wahyuni, S.E. (2012).

Dukungan keluarga dan harga diri pasien kanker payudara di RSUP $H$. Adam Malik Medan. Jurnal Fakultas Ilmu Keperawatan, Universitas Sumatera.

Sinuraya, E.S., (2012). Registrasi kanker berbasis rumah sakit di Rumah Sakit Kanker di Jakarta. Jakarta: Depkes.

Sjolander, C. dan Ahlstrom, G. (2012). The meaning and validation of social support networks for close family of persons with advanced cancer. Journal BMC Nursing.

Tanjung, M.U. dan Nasution, M.L. (2012). Faktor internal dan eksternal kecemasan pada pasien kanker serviks di RSUP H. Adam Malik Medan. Jurnal Fakultas Ilmu Keperawatan, Universitas Sumatera.

Taylor, S.E., Falke, R.L., Shptaw, S.J., dan Lichtman. (1986). Social support, support groups, and the cancer patient. Journal of Consulting and Clinical Psychology. 1986. vol.54, No.5, 608-015.

Taylor, S.E. (1999). Health psychology. $4^{\text {th }}$ ed. Boston: McGraw Hill.

Weis, J. (2003). Support groups for cancer patients. Journal Support care Cancer.

Wijaya, A.M. (2011). Data Riskesdas: perempuan merupakan kelompok yang paling banyak terserang kanker.

World Health Organization (1997). WHOQOL measuring quality of life. 
Xara, S. Amaral, T.F. dan Parente, B. (2011). Undernutrition and quality of life in nonsmall cell lung cancer patients. Journal Rey Port Pneumol. 2011; 17 (4): 153-158.

YKI-Jakarta Race. (2012). http://yayasankankerindonesia.org/20 12/yki-jakarta-race/. Oktober, 23. 2012. 